\title{
Seaweed Species Diversity from Veraval and Sikka Coast, Gujarat, India
}

\author{
Shivani Pathak* , A. J. Bhatt, U. G. Vandarvala and U. D. Vyas \\ Department of Fisheries Resource Management, College of Fisheries Science, \\ Veraval, Gujarat, India \\ *Corresponding author
}

\begin{abstract}
A B S T R A C T
Keywords

Seaweeds diversity, Veraval, Sikka

Article Info

Accepted:

24 October 2020

Available Online:

10 November 2020

The aim of the present investigation focused on a different group of seaweeds observed from Veraval and Sikka coasts, Gujarat from September 2019 to February 2020, to understand their seaweeds diversity. Seaweed diversity at Veraval and Sikka coasts has been studied for six months the using belt transect random sampling method. It was observed that seaweeds were not found permanently during the study period but some species were observed only for short periods while other species occurred for a particular season. A total of 50 species of seaweeds were recorded in the present study, of which 17 species belong to green algae, 14 species belong to brown algae and 19 species of red algae at Veraval and Sikka coasts. Rhodophyceae group was dominant among all the classes. There were variations in species of marine macroalgae between sites and seasons.During the diversity survey, economically important species like Ulva lactuca, $U$. fasciata, Sargassum sp., and Caulerpa sp., were reported. Among them, Sargassum spp. was highly dominated followed by Gracilaria spp. The comparative study at two different locations that is Veraval and Sikka coasts gives an idea about the availability of seaweed resource diversity variation from both the sites.
\end{abstract}

\section{Introduction}

The southwest coast of India that is Gujarat is situated on the north -western part of peninsular India $\left(20^{\circ} 1^{\prime}\right.$ to $24^{\circ} 7 \mathrm{~N}$ and $68^{\circ} 4^{\prime}$ to $74^{\circ} 4^{\prime}$ E) which is a unique marine habitat infested with diverse macroalgae species. Gujarat has $1,600 \mathrm{~km}$ of coastline -the longest coastline of the country (GEC, 2012). The Saurashtra coast is the long stretches of rocky, coralline, and limestone substrate of both intertidal and shallow subtidal water which are rich quantities of seaweed algae biodiversity.
About $90 \%$ of the marine plants belong to one group of algae or the other. Many of these algal groups are now represented mainly as seaweeds. The term seaweed collectively denotes the group of a photosynthetic nonflowering plant with no distinguishable root, stems, and leaves; those are lives either in marine or brackish water environments (GEC, 2012). Seaweeds are generally known as multicellular benthic marine macroalgae that possessing chlorophyll and capable of photosynthesis. Seaweeds can reproduce sexually as well as asexually. Seaweeds are found in the coastal region between high tide 
to low tide i.e. intertidal region and in the subtidal region up to a depth where photosynthetic light is available. They constitute one of the important living resources found mostly on a mudflat and rocky coastal wetlands, coral reefs and lagoons, estuaries, attached to the bottom on solid substrates such as rocks in the intertidal zones, washed up on beaches floating on the oceanic surface, and also in giant underwater forests, dead corals, pebbles, shells and plants (Sahayaraj et al., 2014).

Seaweeds are a group of primitive nonflowering marine plants. They were ecologically and biologically important renewable resources of the marine ecosystem. They also contribute to primary production and provide habitat to flora and fauna. Seaweeds are traditionally been used by the western food industry for their polysaccharide extractives - alginate, carrageenan, and agar also contain compounds with potential nutritional benefits. Seaweeds have been approved for human consumption as that of vegetables and condiments, thus opening new opportunities for the food industry (Mabeau and Fleurence, 1993).

During the last 70 years, several studies have been undertaken on different aspects of marine algae from different parts of the Indian coast. The first checklist of Indian marine benthic algae was published in 1970 Krishnamurthy and Joshi (1970) reported 495 seaweed species along the Indian coast comprising 36 species of Chlorophyceae, 33 species of Phaeophyceae, 98 species of Rhodophyceae, and 6 species of other genera from Gujarat coast. In 2001, Oza and Zaidi (2001) reported a total of 844 species of seaweed all along the Indian coast. The whole diversity comprises 216 species of Chlorophyta, 191 species of Phaeophyta, 434 species of Rhodophyta, and 3 species of Xanthophyta. Recently, Jha et al., (2009) reported 198 seaweed species from the Gujarat coast.

Although a considerable amount of work has been done on marine algae of the Indian region, still we required for compilation of Marine Algal Flora of India, because of a large scale of species extinction. Thus to fulfill the notable lacunae from the present study locations about marine algal diversity are going to be done from the present study. Diversity of marine macroalgae are affected by local environmental productivity and degree of exposure to disturbances like high temperatures, desiccation stress, herbivores, and competition with coastal fauna and flora (Figueiredo and Creed, 2009). The impacts of ongoing anthropogenic activities on climate change in seaweed dominated ecosystems remain largely affected (Harley et al., 2012). Therefore present study was conducted to define the species diversity of available seaweed resources along the coastal waters off Veraval and Sikka coast, Gujarat.

\section{Materials and Methods}

\section{Study area}

The present study was conducted at two places of the Western coast of Gujarat, India i.e. Veraval and Sikka coasts. The Veraval coast is situated at $20^{\circ} 54^{\prime} \mathrm{N}$ latitude and $70^{\circ} 21^{\prime}$ $\mathrm{E}$ longitudes. It has a flat rocky intertidal belt provided with many tidal pools and crevices. Here northwest side the temple of Jaleshwar founded. Where the northeast side Dargah was situated. Behind the lighthouse studied area has been selected. Sikka Coast is situated at $22^{\circ} 25^{\prime} 55.85^{\prime \prime} \mathrm{N}$ latitude and $69^{\circ} 50^{\prime} 29.69^{\prime \prime} \mathrm{E}$ longitudes which is situated at the coast of Marine National Park Jamnagar, the mouth of Gulf of Kutchh on the north-westernmost part of Saurashtra in Gujarat and is one of the most important places of interest for algal growth in India (Figure 1). 


\section{Sampling period}

The study will be conducted for six months and it will be initiated from September-2019 and it will continue up to February-2020. This sampling survey was selected to get an idea of seaweed diversity at the difference between two different locations and seasons.

\section{Sampling method}

The belts transect random sampling method was used for the quantitative assessment of seaweeds in the selected sites. A quadrant measuring $1 \mathrm{~m}^{2}$ area was placed at the sampling points during low tide. The species diversity which was available along the selected study locations were collected and at the laboratory identified by using standard references material (Kamboj et al., 2019).

\section{Results and Discussion}

At Veraval and Sikka coasts, first thoroughly surveyed to get an idea of the coastal characteristics like climatic condition and to make a qualitative assessment of the seaweed flora inhabiting there, throughout the study period. At the Veraval coast, a total of 39 seaweed species were observed throughout the study period. Out of those, 14 species were Chlorophyceae, 9 species were Phaeophyceae, and 16 species were Rhodophyceae. The ratio of Chlorophyceae: Phaeophyceae: Rhodophyceae was 14:9:16. In percentage, $34.50 \%$ were Chlorophyceae, $30.28 \%$ Phaeophyceae, and $35.21 \%$ Rhodophyceae species were recorded (Figure 1) whereas, at Sikka coast, 41 seaweed species were observed throughout the study period. Out of those, 14 species were Chlorophyceae, 11 species were Phaeophyceae, and 16 species were Rhodophyceae. The ratio of Chlorophyceae: Phaeophyceae: Rhodophyceae was 14:11:16. The major part of the stranded seaweed is represented by sixteen species of Rhodophyta accounting for $35.61 \%$, followed by 14 species of Chlorophyta with $34.24 \%$ and 11 species of Phaeophyta with $30.13 \%$ (Figure 1). Thus species of red algae show more dominance in the seaweed flora at both the coasts.

Red algae grow better in the lower littoral zone and maybe more tolerant of the tropical environmental conditions. That may be the reason for the good growth of Rhodophyceae (red algae) as compared to Chlorophyceae of the Phaeophyceae. Chauhan (1994), Joshi and Murthy (2004), and Jha et al., (2009) also observed more number of Rhodhophycea compared to Phaeophyceae of the Chlorophyceae. During the diversity survey, economically important species like Ulva, Caulerpa, Sargassum, Padina, and Gracilaria were reported. Among them, Sargassum spp. was highly dominated followed by Gracilaria spp.

During the survey, it is hypothesized that in general Green algae and Brown algae are observed during the initial months of the survey i.e. September to January while the majority of Red algae are found from January to February months.

Results of the present study are satisfied with earlier reports of Chauhan and Mairh, (1979) along the Saurashtra coastline, Rao et al., (2011) in the Bhimili coast, east coast of India, Chakraborty and Bhattacharya (2012) from Sikka and Vadinar, Gulf of Kutchh, India, Domettila et al., (2013) along Muttom coastal waters of the southwest coast of India, Reddy et al., (2014) in seaweed resources of India, and Naik et al., (2015) in Karwar Bay. In Gujarat waters of Kutch regions four islands viz., Chhad, Debeka- Mundeka, Goose, and Narrara, 70 seaweed species were recorded which comprises 24 Green algae, 15 Brown algae, and 31 Red algal species. The 
numbers of seaweeds species found in Chad, Dadeka-Mundeka, Goose, and Narara were 44, 49, 33, and 31 respectively (Roy et al., 2015). A similar observation was recorded in the present investigation also. Ishakani et al., (2016) from the Veraval coast reported a total of 67 species comprises of 21 species of Chlorophyta, 14 species of Phaeophyta, and 32 species of Rhodophyta species which revealed that the results of the present study are much similar to earlier researchers (Fig. $1-5)$.

Table.1 Taxonomic classification of seaweed species from

Veraval and Sikka coasts, Gujarat, India

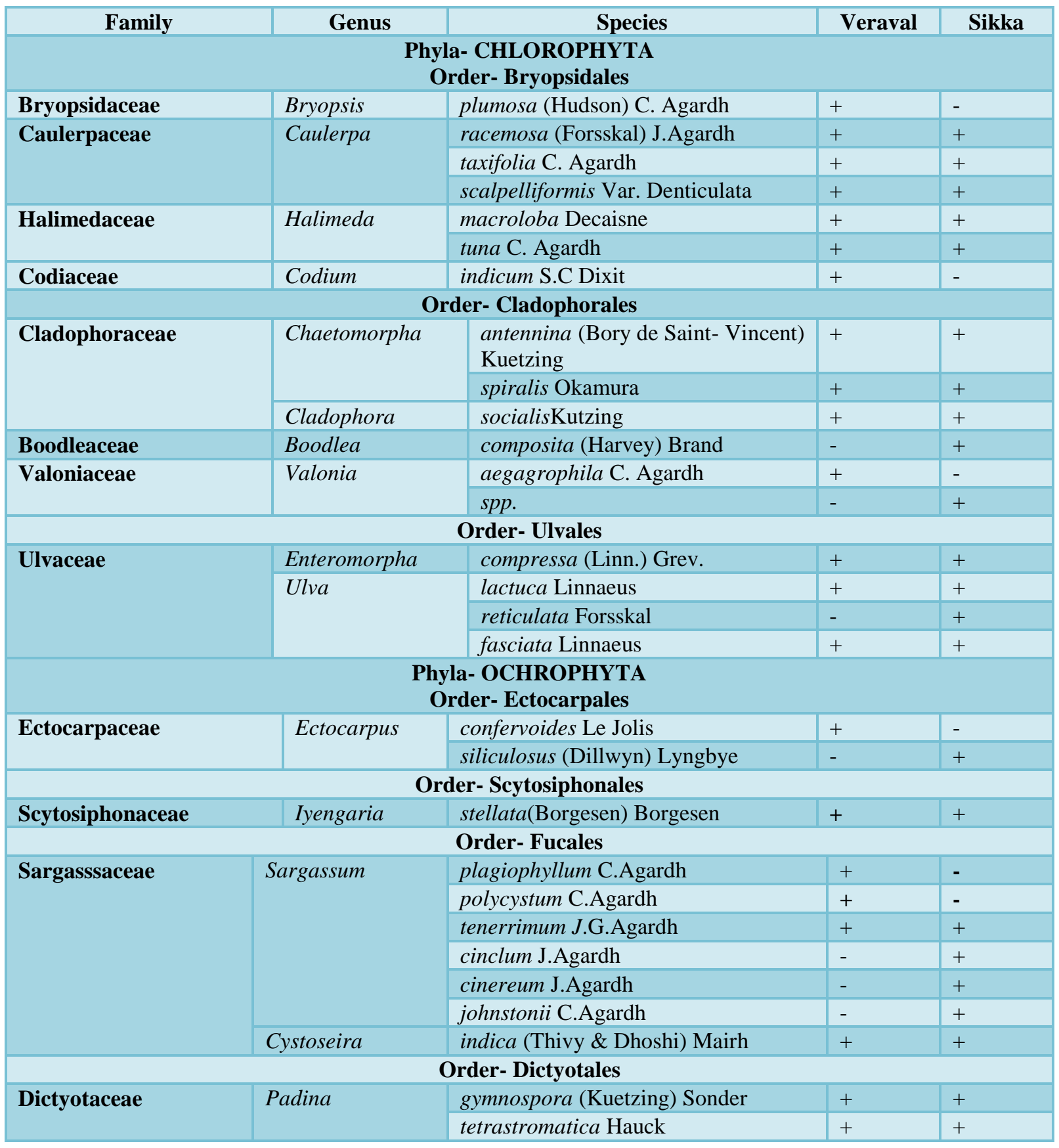




\begin{tabular}{|c|c|c|c|c|}
\hline & & boergesenii Allender \& Kraft & - & + \\
\hline & Spatoglossum & asperum J. Agardh & + & + \\
\hline \multicolumn{5}{|c|}{$\begin{array}{l}\text { Phyla-RHODOPHYTA } \\
\text { Order-Ceramiales }\end{array}$} \\
\hline \multirow[t]{3}{*}{ Rhodomelaceae } & Acanthophora & spicifera (Vahl) Boergesen & + & + \\
\hline & Chondria & armata (Kutzing) Okamura & + & + \\
\hline & Polysiphonia & platycarpa Borgesen & + & - \\
\hline \multirow[t]{3}{*}{ Ceramiaceae } & \multirow[t]{3}{*}{ Ceramium } & Rubram (Huds.) Ag. & + & + \\
\hline & & cruciatum FS Collins \& Hervey & + & + \\
\hline & & tenerrimum (G.Martens) Okamura & - & + \\
\hline Delesseriaceae & Platysiphonia & delicate (Clemente) Cremades & - & + \\
\hline \multicolumn{5}{|c|}{ Order- Gigartinales } \\
\hline Hypneaceae & Hypnea & musciformis (Wulf.) Lamour & + & + \\
\hline \multicolumn{5}{|c|}{ Order- Nemaliales } \\
\hline \multirow[t]{3}{*}{ Galaxauraceae } & \multirow[t]{3}{*}{ Scinaia } & moniliformis J.Agardh & + & - \\
\hline & & hatei Borgesen & + & + \\
\hline & & carnosa (Kutzing) J.Agardh & - & + \\
\hline \multicolumn{5}{|c|}{ Order- Gelidiales } \\
\hline \multirow[t]{2}{*}{ Gelidiellaceae } & Gelidiella & $\begin{array}{l}\text { acerosa (Forsskal) J. Feldmann \& G. } \\
\text { Hamel }\end{array}$ & + & + \\
\hline & Gelidium & pusillum (Stackhouse) Le Jolis & + & + \\
\hline \multicolumn{5}{|c|}{ Order-Gracilariales } \\
\hline \multirow[t]{3}{*}{ Gracilariaceae } & \multirow[t]{3}{*}{ Gracilaria } & corticata (J.Agardh) J.Agardh & + & + \\
\hline & & foliifera (Forssk.) Boergs. & + & + \\
\hline & & salicornia (C.Agardh) Dowson & + & + \\
\hline \multicolumn{5}{|c|}{ Order: Halymeniales } \\
\hline \multirow[t]{2}{*}{ Halymeniaceae } & \multirow[t]{2}{*}{ Halymenia } & venusta Borgesen & + & + \\
\hline & & porphyraeformis P.G.Parkinson & + & - \\
\hline \multicolumn{5}{|c|}{ Order: Rhodymeniales } \\
\hline Champiaceae & Champia & indica Boergs. & + & + \\
\hline
\end{tabular}

Fig.1 Map showing the study area of Veraval and Sikka coast, Gujarat
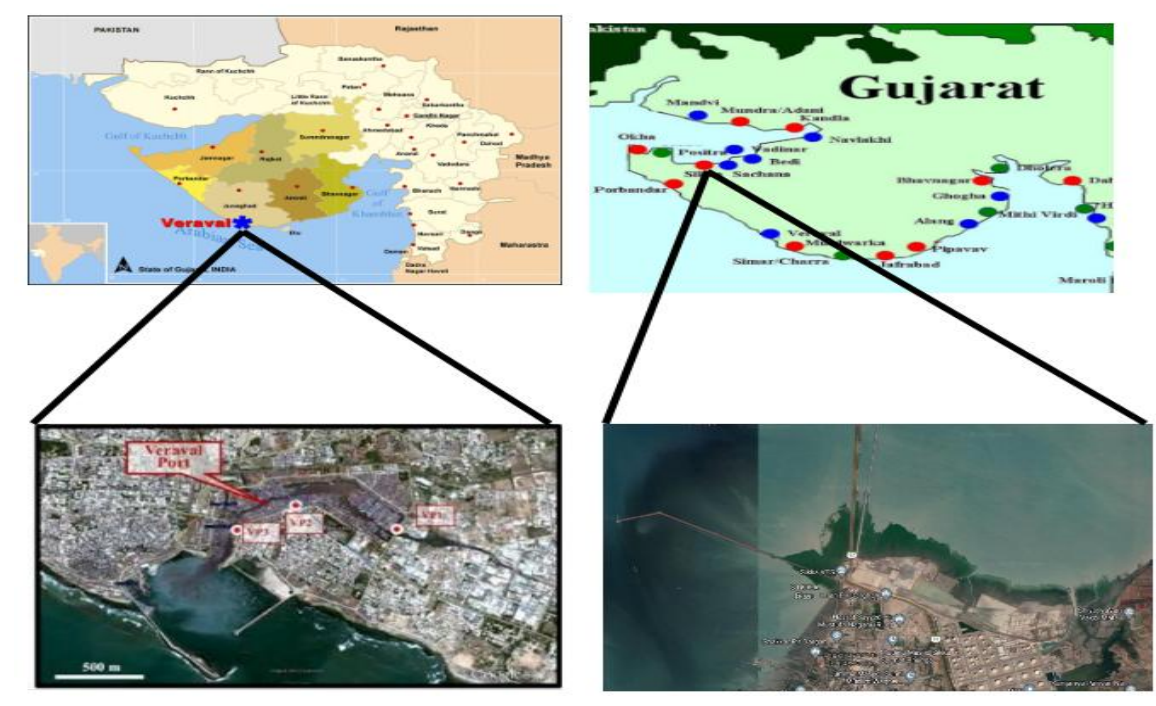
Fig.2 Class-wise percentage distribution of species diversity at Veraval and Sikka coasts

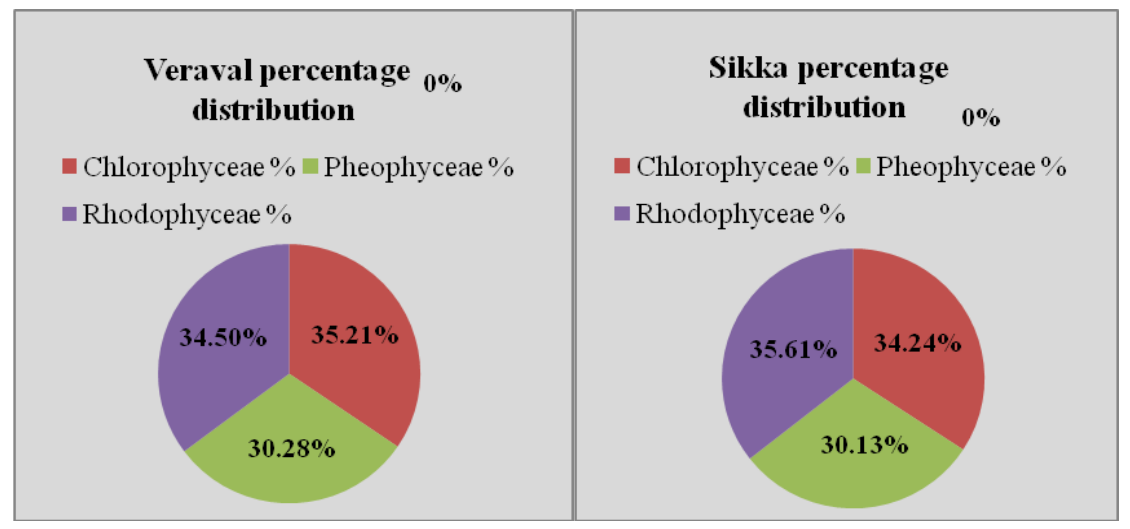

Fig.3 Chlorophyceae - green algae species at Veraval and Sikka coasts

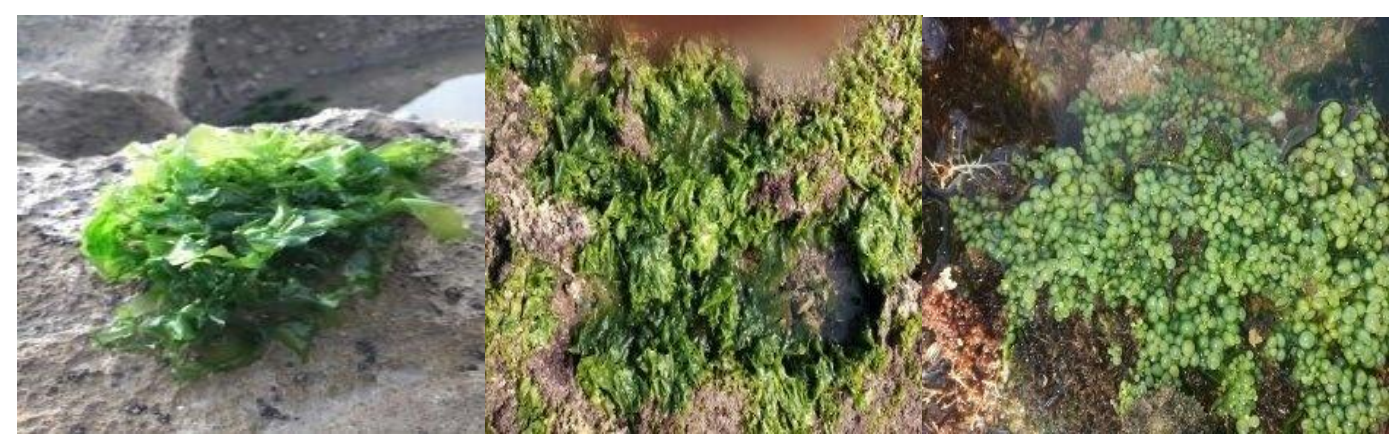

Ulva lactuca

Ulva fasciataCaulerpa racemosa
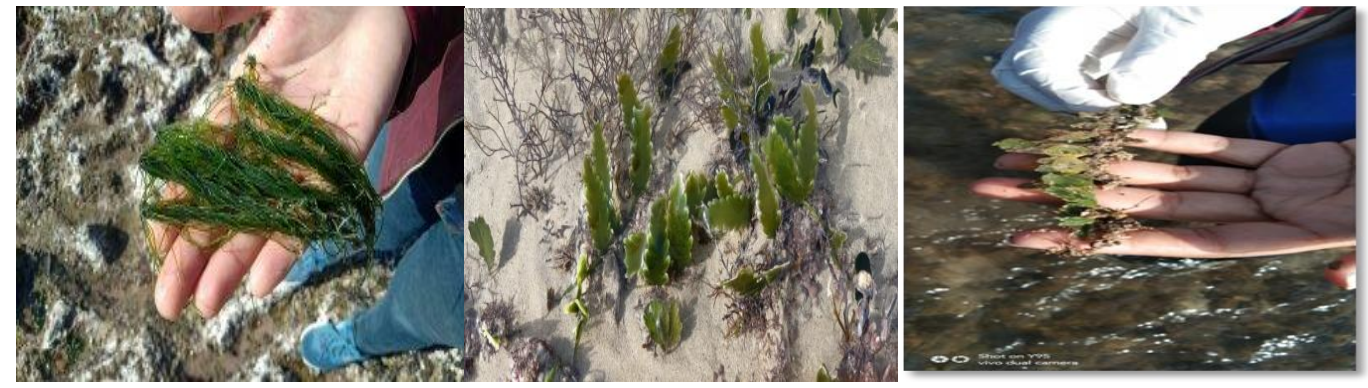

Chaetomorpha antennina
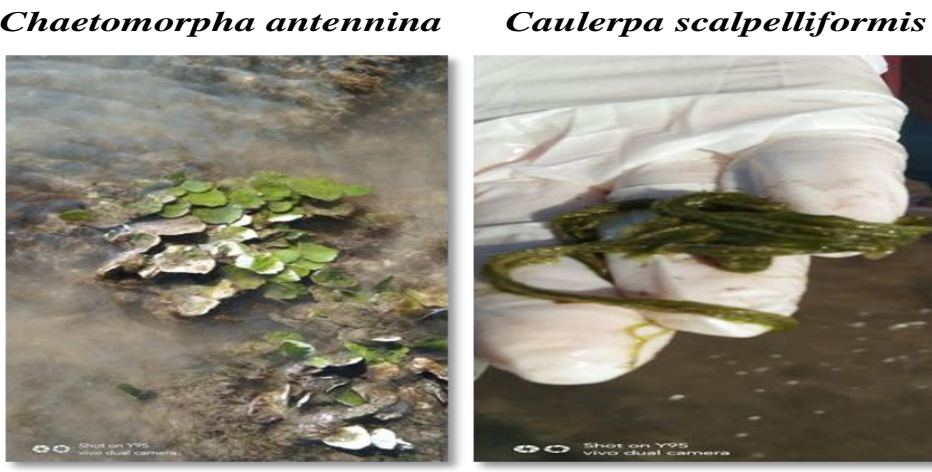

Caulerpa taxifolia

Halimeda macroloba
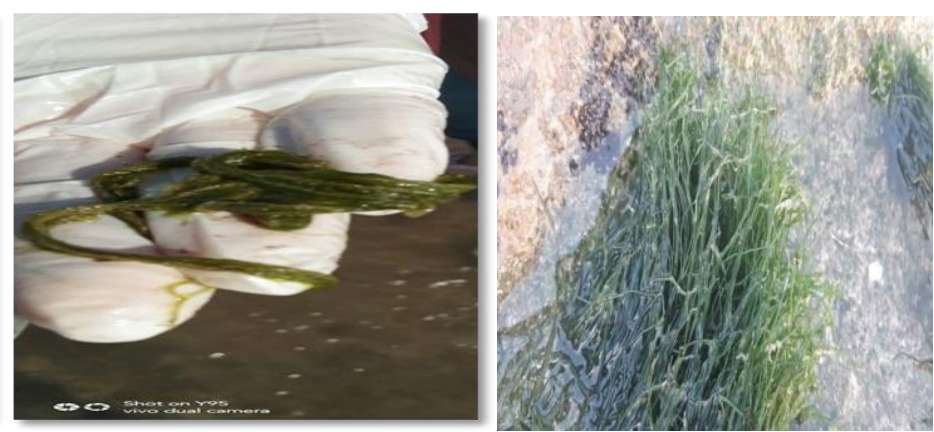

Cladophora socialis Vallonia spp. 
Fig.4 Phaeophyceae - brown algae species at Veraval and Sikka coasts
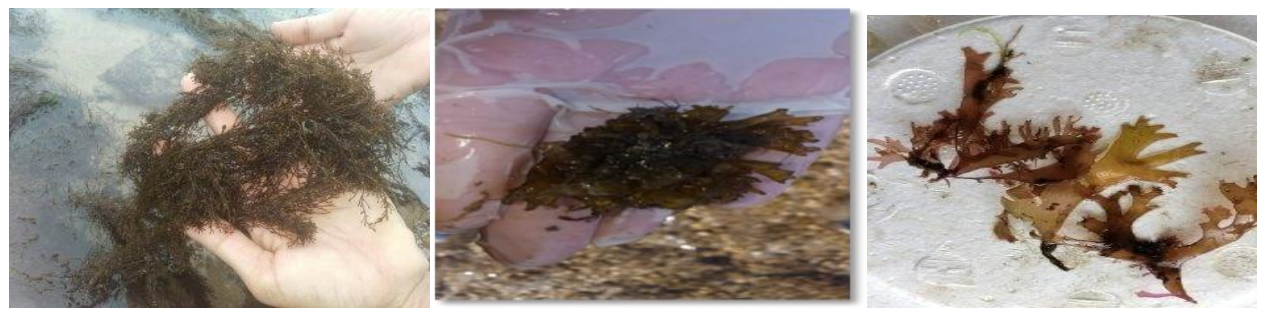

Cystoseira indica Iyengari stellataspatoglossum asperum

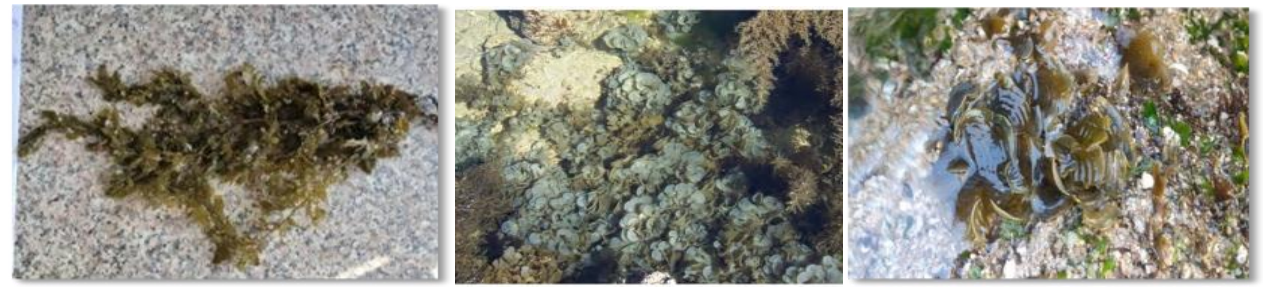

Sargassum polycystumPadina gymnospora Padina tetrastromatica

Fig.5 Rhodophyceae - red algae species at Veraval and Sikka coasts
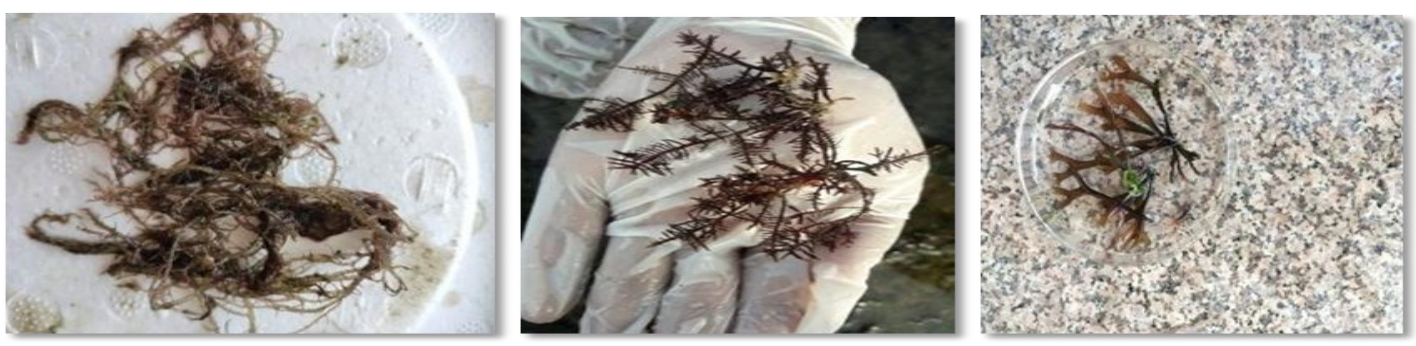

Hypnea musciformis Gelidiella acerosa

\section{Gracilaria corticata}
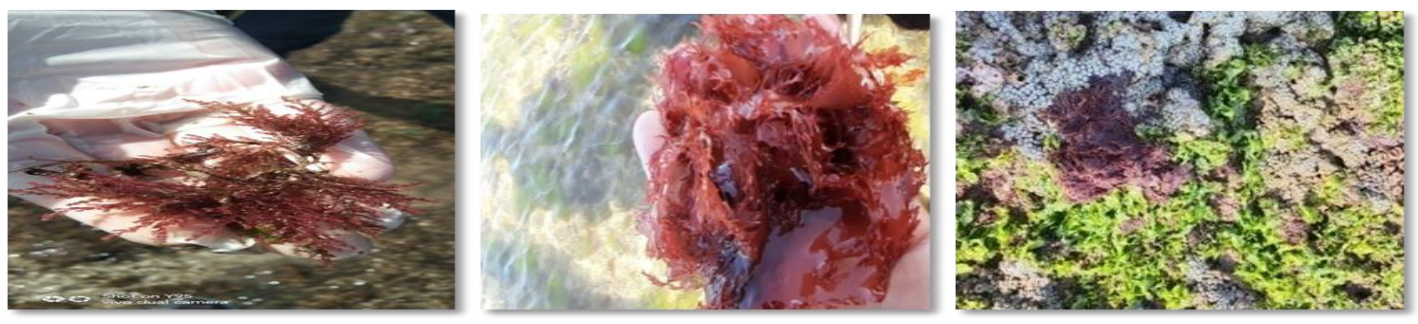

Acanthophora spicifera

Halymenia venustaPlatysiphonia delicate
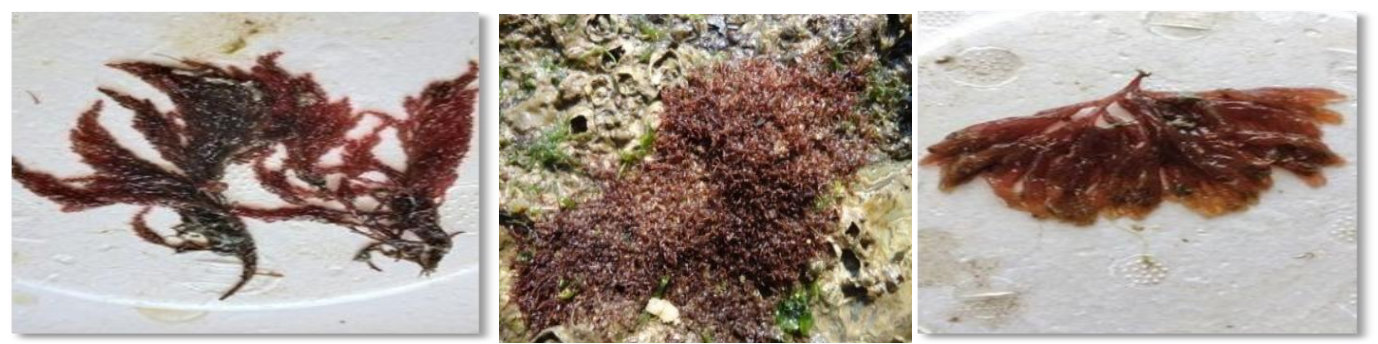

Scinaia carnosaChampia indicaGelidium pusillum 
Taxonomic classification of collected seaweed species at Veraval and Sikka coasts

Taxonomically, a total of $39 \& 41$ seaweed species belonging to 3 phyla (Chlorophyta, Ochrophyta, and Rhodophyta), 4 classes (Bryopsidophyceae, Florideophyceae, Phaeophyceae, and Ulvophyceae), 14 orders, and 19 families were investigated in the Veraval and Sikka coast (Table 1).

A total of 50 species of seaweeds were recorded in the present study, of which 17 species belong to Chlorophyceae viz., Bryopsis plumosa, Caulerpa racemosa, C. taxifolia, C.scalpelliformis, Ulva fasciata, U.lactuca, U.reticulate, Enteromorpha compressa, Halimeda tuna, H.macroloba, Codium indicum, Chaetomorpha spiralis, Chaetomorpha antennina, Valonia aegagrophila, Cladophora socialis, Boodlea composita, and Vallonia sp. In brown algae, 14 species- Cystoseira indica, Sargassum plagiophyllum, S. polycystum, S. tenerrimum, S. cinclum, S. cinereum, S. johnstonii, Padina tetrastromatica,

P.gymnospora, P.boergesenii, Spatoglossum asperum, Ectocarpus confervoides, Ectocarpus siliculosus, Iyengaria stellata. In red algae, 19 species viz., Acanthophora spicifera, Chondria armata, Polysiphonia platycarpa, Ceramium rubram, Ceramium cruciatum, $C$. tenerrimum, Platysiphonia delicate, Champia indica, Gelidiella acerosa, Gelidium pusillum, Gracilaria corticata, Gracilaria foliifera, Gracilaria salicornia, Halymenia venusta, Halymenia porphyraeformis, Hypnea musciformis, Scinaia moniliformis, S.carnosa, S. hatei.

There were altogether 26 genera, Out of which 9 genera and 14 species of green algae, 6 genera and 9 species of brown algae, and 11 genera and 16 species of red algae were recorded at Veraval coast whereas, at Sikka coast, total 25 genera out of which 8 genera and 14 species of green algae, 6 genera and 11 species of brown algae, and 11 genera and 16 species of red algae were recorded during the study period.

The present study concluded that Sikka has a higher diversity of seaweeds compared to the Veraval coast. Both study locations represent different conditions, the coastal environment in the Saurashtra region especially along the Veraval coast where anthropogenic activities were affected by the coastal ecological communities. The climatic change and global warming as well as anthropogenic activities will have considerable adverse impacts over natural resources particularly seaweeds. While the Sikka coast is under marine protected area so less anthropogenic activities are affected by the coastal environment which increased the productivity of marine species.

Seaweed diversity information could also provide a baseline for future more complex ecological studies, planning the conservation and sustainable use of inshore marine resources, useful as an indicator of climatic change and coastal management as well as applied aspects of the uses of seaweed.

\section{Acknowledgements}

The authors would like to thank Dr. A. J. Bhatt, M.Sc. (Marine Science), Ph.D., Assistant Professor, and Head, Fisheries Resource Management, and the respectable Dr. A. Y. Desai, Dean and Principal, College of Fisheries, Veraval, Junagadh Agricultural University, Gujarat for his kind co-operation, valuable suggestions, constant help, and inspiration throughout this research work.

\section{References}

Chauhan, V. D. and Mairh, O. P. 1979. Report on survey of economic seaweeds of Saurashtra coast, India. Seaweed Research and 
Utilisation. 14 (2): 21-41.

Chauhan, Z. T. 1994. Ecological studies of Ulva species from Saurashtra coast, Ph.D. Thesis, Saurashtra University, India.

Chakraborty, S. and Bhattacharya, T. 2012. Nutrient composition of marine benthic algae found in the Gulf of Kutch coastline, Gujarat, India. J. Algal Biomass Utln. 3(1): 32-38.

Domettila, C.; Brintha, T. S.; Sukumaran, S. and Jeeva, S. 2013. Diversity and distribution of seaweeds in the Muttom coastal waters, south-west coast of India. Biodiversity Journal. 4(1): 105-110.

Figueiredo, M. A. O. and Creed, J. C. 2009. Marine Algae and Plants. In: Kleber Del Claro, Paulo S. Oliveira \& Victor RicoGray Eds, Tropical Biology and Conservation Management. Botany Vol. IV. Encyclopedia of Life Support Systems. Eolss Publishers Co. Ltd; Oxford, United States. pp: 1-7.

Gujarat Ecological Commission. 2012. Study of seaweed diversity along the islands of the Gulf of Kachchh, Gujarat. The government of Gujarat, Gujarat Ecological Commission, Gandinagar. 81p.

Harley, C. D. G.; Kathryn, M. A.; Kyle, W. D.; Jennifer P. J.; Rebecca, L. K. and Theraesa, A. C. 2012. Effects of Climate Change on Global Seaweed Communities. J. Phycol.

Ishakani, A. H.; Joshi, N. H.; Ayaz, M.; Sumara, K. and Vadher, K. H. 2016. Assessment of seaweed diversity at Veraval coast, Gujarat. Journal of Experimental Zoology. 19(2):863-868.

Joshi, N. H. and Murthy, S. 2004. Ecological studies on Sargassum species of Port Okha (Gujarat). Seaweed Research and Utilization. 26 (1\&2): 63-71.

Jha, B.; Reddy, C. R.; Thakur, M. C. and Rao, M. U. 2009. Seaweeds of India, the Diversity and Distribution of Seaweeds of Gujarat
Coast. Developments in Applied Phycology, Springer, Dordrecht. 3(12), pp. 216.

Krishnamurthy, V. and Joshi, H. V. 1970. A check-list of Indian marine algae. Central Salt \& Marine Chemicals Research Institute, Bhavnagar. p. 36.

Kamboj, R. D.; Das, L. and Palanisamy, M. 2019. Pictorial guide to seaweeds of Gulf of Kuchchh, Gujarat. Gujarat Ecological Education and Research (GEER) Foundation, Gandhinagar. pp. 367.

Naik, U. G.; Beligiriranga, V. and Haragi, S. B. 2015. Seaweeds of Karwar Bay, Arabian Sea, West Coast of India - A Diversity Profile. International Journal of Science and Nature. 6(4): 728-732.

Oza, R. M. and Zaidi, S. H. 2001. A revised checklist of Indian marine algae. Central Salt and Marine Chemicals Research Institute, Bhavnagar. pp. 296.

Rao, K. S.; Murty, P. M.; and Narasimha Rao, G. M. 2011. Seasonal Studies on Marine algae of the Bhimili Coast, East Coast of India. J. Algal. Biomass. Utln. 2: 69-82.

Reddy, C. R. K.; Rao S. P. V.; Ganesan, M.; Eswaran, K.; Zaidi, S. H. and Mantri, V. A., 2014. The Seaweed Resources of India. In: A. T. Critchely, M. Ohno and D.B. Largo edn. World Seaweed Resources in DVD format, ETI Information Services Ltd., Wokingham, Berkshire, UK. pp: 25.

Roy, S.; Salvi, H.; Brahmbhat, B.; Vaghela, N.; Das, L. and Pathak, B. 2015. Diversity and distribution of seaweeds in selected reefs and island in Gulf of Kachchh. Seaweed Research and Utilization. 37(1): 12-19.

Sahayaraj, K.; Rajesh, S.; Asha, A.; Rathi, J. M. and Raja, P. 2014. Distribution and diversity assessment of the marine microalgae at four southern districts of Tamil Nadu, India. Indian Journal of GeoMarine Sciences. 43(4): 607-616.

\section{How to cite this article:}

Shivani Pathak, A. J. Bhatt, U. G. Vandarvala and Vyas, U. D. 2020. Seaweed Species Diversity from Veraval and Sikka Coast, Gujarat, India. Int.J.Curr.Microbiol.App.Sci. 9(11): 3667-3675. doi: https://doi.org/10.20546/ijcmas.2020.911.441 